\title{
KELUARGA SEBAGAI MEDIA PENDIDIKAN TAUHID (Telaah Atas Pemikiran Ismail Raji Al-Faruqi dan Lamya Al-Faruqi)
}

\author{
Oleh: M. Bekti Khudari Lantong
}

\begin{abstract}
Human association has had a long story which three institutions had struggled to dominate. The first is the family, which has blood and heredity for bases. The characteristic it engenders in humans are innate and immutable. Certainly, family-living engenders in humans other characteristics which are acquired through association. These, however, are not necessary. Members born to one family may successfully be brought up as members of another; but the innate characteristic remain unchanged. The family was declared by God an intrinsic order of creation. "O..Humankind, revere your Lord, Who created you of a single soul and created of it its spouse.. It is of God's providing that He created of yourselves spouses in whom to find quiescene, and established between you love and compassion...that He generated from you and your spouses your children and grandchildren". Parents, their children and grandchildren, and the love and compassion relation between them, constitute an immutable pattern of God creation. This is the family in its nuclear and extended forms spanning three generations. Islam not only acknowledges it but has girded it with law. Unlike any other social system, the law of Islam articulated the relations of all members of the extended family in order to insure proper functioning of all of them. Marriage and divorce, legitimacy and dependency, earnings and supports, inheritance, and the members' mutual rights and duties have been detailed by the shari'ah. ${ }^{1}$
\end{abstract}

Keywords : Family, Education, Tauhid (Belief in One Supreme God)

\section{Pendahuluan}

Di dalam Oxford advanced learner's dictionary, family atau keluarga didefinisikan sebagai: (1) a group of parents and children; (2) all those persons descended from a common ancestor; dan (3) a group of living things (plants, animals, etc.) or of languages, with common characteristic and a common source. ${ }^{2}$ Mungkin definisi ini terlalu umum, sehingga tidak merepresentasikan konsep keluarga yang sesungguhnya. Tapi, yang jelas, inilah konsep keluarga menurut orang-orang "Barat"

\footnotetext{
${ }^{1}$ Lihat Ismail Raji Al-Faruqi, Trialogue of the Abrahamic Faiths, Chap.7; The Nation-State and Social Order in the Perspective of Islam, (Maryland: Amana Publication, 1982), p.49

2 Lihat Oxford Advanced Learner's Dictionary of Current English, (Gen. ed.) AS. Hornby, (England: Oxford University Press, 1974), p. 309, see the word; family
} 
yang liberal dan sekuler. Hal ini akan nampak manakala dihadapkan vis a vis dengan konsep keluarga menurut Islam. Di dalam Islam, keluarga harus dibentuk berdasarkan nilai-nilai moral yang bersumber dari tuntunan ilahi, sehingga arah dan tujuan keluarga bukan semata-mata sebagai ajang pemenuhan nafsu birahi antara dua orang yang berlainan jenis, tetapi juga merupakan 'wadah' untuk mengejawantahkan nilai-nilai ilahiah. Sedangkan dalam pandangan orang-orang "Barat", keluarga tak lebih dari sebuah lembaga yang mengekang kebebasan individual dan membebani dengan berbagai macam aturan yang tak masuk akal. Dan segala sesuatu yang mengekang kebebasan dan memberatkan harus disingkirkan sejauh mungkin (to be eliminated as far as possible) dari kehidupan ini. Tulisan ini akan mencoba mengelaborasi dan menguraikan pokokpokok pikiran Ismail Al-Faruqi dan istrinya, Lamya, khususnya berkenaan dengan pemikiran (konsep) mereka berdua tentang keluarga sebagai sarana atau media untuk pendidikan nilai-nilai ke-tauhid-an dan ke-iman-an.

\section{Biografi Singkat Ismail dan Lamya Al-Faruqi}

Ismail Raji Al-Faruqi lahir 1 Januari 1921 di Jaffa, Palestina. Pendidikan dasarnya dia mulai di madrasah, lalu melanjutkan pendidikan menengah di College des Freres St. Joseph. Pada tahun 1941 Al-Faruqi mengambil kuliah filsafat di American university, Beirut. Setelah meraih gelar Bachelor of Arts, ia kemudian bekerja sebagai pegawai negeri sipil pada pemerintahan Inggris - yang memegang mandat atas Palestina ketika itu - selama empat tahun. Karena bakat kepemimpinannya menonjol, pada usia 24 tahun ia diangkat menjadi gubernur Galilea.

Pada tahun 1948 Palestina dijarah Israel. Al-Faruqi, seperti warga Palestina lainnya, terusir dari tanah kelahirannya. Ia tercatat sebagai gubernur Galilea terakhir yang berdarah Palestina. Setahun menganggur, pada tahun 1949 Al-Faruqi hijrah ke Amerika untuk melanjutkan kuliah. Ia memperoleh gelar master dalam bidang filsafat dari Indiana university. Dua tahun kemudian, ia memperoleh gelar yang sama dari Harvard University. Dan pada tahun 1952 ia memperoleh gelar Ph.D. di Indiana University. 
Merasa pengetahuannya tentang Islam masih kurang, ia lalu kuliah lagi di universitas Al-Azhar, Mesir, selama tiga tahun. Karena kuatnya dorongan untuk belajar pulalah sehingga Al-faruqi memenuhi undangan Wilfred Cantwell Smith untuk bergabung dengan Institute of Islamic Studies di McGill, Kanada, selama dua tahun. Pada tahun 1964, Al-Faruqi kembali ke Amerika dan menjadi 'visiting Professor' pada universitas Chicago dan 'associate professor' bidang agama pada universitas Syracuse. Lalu, pada tahun 1986 hingga wafatnya, menjabat sebagai guru besar agama-agama pada universitas Temple.

Kepedulian Al-Faruqi terhadap Islam dan kaum muslimin diawali dengan komitmennya yang teguh pada Islam. Karena itu, aktifitasnya melampaui batas-batas akademis. Ia dapat disebut sebagai seorang sarjana, aktifis, dan pemimpin sekaligus, yang mendedikasikan diri seutuhnya pada pembaruan dan reformasi. "Bagi Al-Faruqi, kerja adalah dakwah yang sesungguhnya, yaitu pergulatan nyata dalam rangka mengaktualisasikan dan merealisasikan Islam dalam sejarah", demikian pandangan John L. Esposito tentang figur kharismatik tersebut.

Keaktifan Al-Faruqi di berbagai kelompok studi Islam dan keterlibatannya dalam gerakan-gerakan Islam sangat menonjol. Ia adalah tokoh dibalik berdirinya MSA, ISNA, AJISS, AMSS, IIIT, dan banyak lagi lembaga-lembaga lainnya. Dan karena sikap kritisnya terhadap gerakan Zionisme dan negara Israel, akhirnya ia dan istrinya "syahid" dibunuh oleh agen rahasia Israel (Mossad) ${ }^{3}$

Sedangkan Lamya, yang sebelum masuk Islam bernama asli Louis Ibsen, lahir di Montana, Amerika Serikat pada tahun 1926. Karir akademis Lamya dimulai ketika ia masuk universitas McGill, Kanada, tahun 1944. Lalu ia melanjutkan kuliah di universitas Pennsylvania dan universitas Temple, dan meraih gelar doktor pada tahun 1974 dari universitas Syracuse. Belakangan Lamya banyak dikenal sebagai salah seorang sarjana paling otoritatif dalam sejarah musik dan kesenian Islam. Ia mengajar di berbagai

\footnotetext{
${ }^{3}$ Lamya Al-Faruqi, 'Ailah; Masa Depan Kaum Wanita, pent. Masyhur Abadi, (Surabaya: Alfikr, 1997) h. vii-x
} 
universitas di Amerika, bahkan mengajar di Pakistan dan Filipina. Selain menjabat sebagai anggota Dewan Penyunting Jurnal Arts in the Islamic World yang berbasis di London, ia juga dipercaya untuk duduk sebagai salah seorang anggota pokja UNESCO. Iantara karyanya yang monumental adalah The Cultural Atlas of Islam, yang merupakan hasil kolaborasi dengan suaminya, Al-Faruqi. ${ }^{4}$

\section{Problematika Keluarga Modern: Sebuah Refleksi Terhadap Kehidupan Keluarga di Amerika dan Dunia Pada Umumnya}

Sebagaimana telah disebutkan pada bagian awal bahwa Al-faruqi telah menghabiskan sebagian besar hidupnya di Amerika, dan telah berkunjung ke berbagai negara di Eropa dan belahan dunia yang lain, di mana ia telah melihat secara langsung bagaimana lembaga keluarga mengalami "keruntuhan". Menurut Al-Faruqi, di seluruh dunia Barat dan Komunis, lembaga keluarga telah mengalami perubahan radikal. ${ }^{5}$

Di Eropa Barat dan Amerika khususnya, urbanisasi ke pusat-pusat perkotaan dengan tujuan mencari pekerjaan membuat setiap orang kehilangan ciri kepribadian masing-masing. Percampuran jenis kelamin, moralitas yang longgar, kemandirian ekonomi kaum wanita, individualisme, dan pemutlakan naluri alamiah, telah memberikan kontribusi yang sangat besar bagi "kehancuran" lembaga keluarga. Dewasa ini, lebih dari separuh jumlah anak yang dilahirkan di kota-kota besar adalah "anak-anak haram". Keluarga telah berubah menjadi kumpulan hewan, dalam pengertian bahwa lembaga ini hanya ada selama anak-anak secara fisik tak berdaya dan membutuhkan perhatian dan perawatan dari orang tua mereka. Tetapi, begitu anak-anak ini beranjak dewasa, pemenuhan kebutuhan materi hilang dan ikatan kekeluargaan pun terputus. Lebih buruk lagi, keasyikan para orang tua dengan pekerjaan di luar rumah, kelelahan fisik, ambisi untuk mengejar karir, dan tekanan untuk mencari pemuasan emosi di luar rumah, telah melemahkan dan meluluhlantakkan ikatan kasih-sayang dalam keluarga, bahkan ketika anak-anak masih dalam umur yang sangat rawan.

\footnotetext{
${ }^{4}$ Ibid, h. v-vi

${ }^{5}$ Ismail Raji Al-Faruqi, T a u hi d, pent. Rahmani Astuti, (Bandung: Pustaka, 1988) h. 137
} 
Sementara itu, kaum Komunis, dengan diilhami oleh doktrin mereka tentang asalusul masyarakat, sengaja mengganti lembaga keluarga dengan komunal (commune). Mereka menggambarkan kondisi kehidupan "ideal” bagi manusia sebagai suatu keadaan, di mana orang-orang (dari segala jenis kelamin, ras dan umur) hidup di dalam asrama, makan di aula besar, dan menganggap keturunan mereka sebagai anak-anak negara. Meskipun telah banyak komunal yang dibentuk, namun metode pengorganisasian kolektif manusia ini tetap mengalami kegagalan total. Pengambilalihan oleh negara atas tugas para orang tua dalam mengasuh, membina dan mendidik anak-anak mereka telah mengakibatkan melemahnya ikatan keluarga. Sehingga harus dikatakan bahwa konsep ini pun telah gagal, dan tidak bisa diterapkan sama sekali. Oleh karena itu, Al-Faruqi menawarkan konsep keluarga (sebagai wadah pendidikan dan penanaman) Tauhid sebagai solusi terhadap problematika keluarga modern. ${ }^{6}$

\section{Konsep Tauhid Menurut Ismail Al- Faruqi}

Menurut Al-Faruqi, inti keberagamaan seseorang adalah Tuhan. Kalimat syahadah, atau pengakuan penerimaan Islam menegaskan bahwa "Tidak ada Tuhan selain Allah". Allah Swt. menempati posisi sentral dalam perilaku, tindakan dan pemikiran setiap muslim. Kehadiran Tuhan (the existence of God) menjadi "kesadaran" utama seorang muslim, kapan pun dan di mana pun.

Kalimat Tauhid adalah sebuah keyakinan dan kesaksian bahwa "Tidak ada Tuhan selain Allah". Pernyataan yang sangat singkat ini mengandung makna yang Paling Agung dan Paling Kaya dalam seluruh khazanah Islam. Seluruh kekayaan dan keragaman kebudayaan, peradaban, sejarah, pengetahuan, ajaran dan kebijaksanaan Islam dipadatkan dalam satu kalimat pendek ini: La Ilaha illa Allah. Tauhid merupakan pandangan umum tentang realitas, kebenaran, dunia; ruang dan waktu, sejarah manusia dan takdir.

Untuk mengetahui kehendak Tuhan, manusia diberi wahyu; suatu pengungkapan langsung (direct revelation) mengenai apa yang diinginkan Tuhan agar diwujudkan oleh manusia di muka bumi. Manakala wahyu tersebut telah rusak, diselewengkan, atau dilupakan, Tuhan mengulang (kembali) penyampaiannya, dengan mempertimbangkan

\footnotetext{
${ }^{6}$ Ibid, h. 136-137
} 
relatifitas-relatifitas sejarah, dan perubahan-perubahan ruang dan waktu, di mana semuanya bertujuan untuk memudahkan manusia memperoleh pengetahuan tentang perintah-perintah moral. Begitu juga, manusia diberi kelengkapan indrawi; akal dan pengetahuan, intuisi dan semua kesempurnaan yang dibutuhkan untuk mengetahui kehendak Ilahi. Sebab, kehendak-kehendak tersebut bukan hanya dapat ditemukan di alam raya yang bersifat kausalitas, melainkan juga dalam perasaan-perasaan dan hubungan antar manusia (social relation and communication).

Salah satu sumbangan pemikiran Al-Faruqi yang sangat penting adalah konsep tentang Islamisasi Ilmu Pengetahuan (Islamization of Knowledge and Science). Pemikiran ini muncul karena Al-Faruqi menilai bahwa perkembangan ilmu pengetahuan dan teknologi modern sudah menyimpang jauh dari ajaran Tauhid, dalam artian ilmu pengetahuan dan teknologi dikembangkan semata-mata untuk memenuhi hasrat intelektual dan nafsu duniawi manusia. Akibatnya, terjadi kerusakan alam dan ekosistem yang luar biasa. Ditambah lagi dengan semakin banyaknya persoalan-persoalan sosialkemasyarakatan, dekadensi moral, gaya hidup free life dan free sex, serta runtuhnya lembaga keluarga. Dalam hal ini, salah satu masalah penting yang dielaborasi oleh AlFaruqi adalah bagaimana merekonstruksi kembali (reconstruction) peran dan fungsi (role and function) keluarga sebagai sebuah elemen dan institusi yang sangat urgent di dalam merekayasa masyarakat menuju masyarakat Tauhid.

\section{Keluarga Sebagai Media Pendidikan dan Penanaman Ajaran Tauhid}

Menurut Al-Faruqi, pemenuhan tujuan Tuhan pada manusia mensyaratkan bahwa manusia harus kawin, melahirkan keturunan, dan hidup bersama sehingga tersedia sebuah "wadah" bagi realisasi hubungan antara sesama manusia, di mana unsur-unsur moral dari kehendak ilahi dapat terealisir melalui keputusan dan tindakan manusia. Wadah ini terdiri dari empat bagian: individu, keluarga, suku, ras atau bangsa, dan ummat (Arab: ummatun).

\section{a. Individu}


Setiap pemenuhan moralitas mensyaratkan keterlibatan subyek atau individu dalam hubungan etis dengan dirinya sendiri. Mengakui eksistensi diri sendiri, melestarikan, mengembangkan, dan menundukkannya pada determinasi nilai-nilai moral adalah syarat mutlak bagi manusia, karena tanpanya hidup manusia tidak akan bermakna (meaningless).

\section{b. Ummat}

Adapun ummah berfungsi membangun hubungan manusia atas dasar agama atau ideologi, dan memperluas lingkupnya kepada semua manusia tanpa memandang keturunan atau ciri-ciri sosial seperti bahasa, sejarah atau warna kulit. Sebagaimana firman Allah QS. al-Anbiya' [21]:92
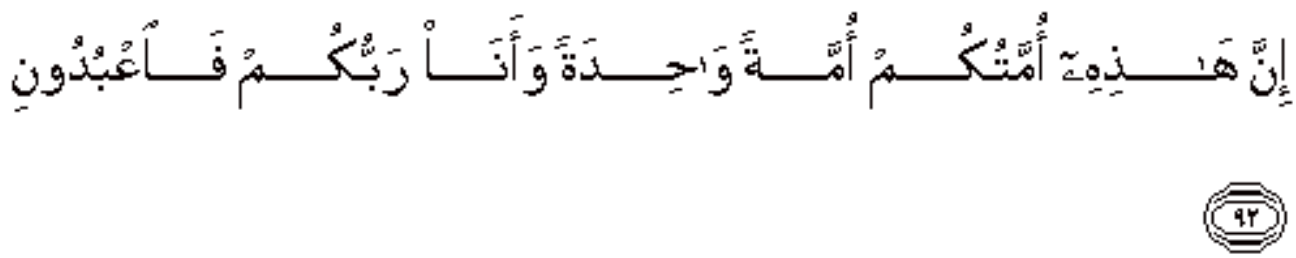

Artinya: Sesungguhnya ummatmu ini adalah ummat yang satu, dan Aku adalah Tuhanmu, karena itu, hendaklah kalian mengabdi kepada-Ku

Hubungan ummat lebih manusiawi dan melestarikan harkat manusia, sedangkan hubungan suku dan ras melanggar harkat tersebut dengan mendasarkan keeksklusifannya pada keturunan. Itulah sebabnya mengapa Islam menghapuskan (tradisi) kesukuan dan rasialisme dan menggantinya dengan (konsep) ummat.

\section{c. Keluarga}

Keluarga merupakan unit sosial yang paling utama. Arti penting keluarga dalam tata kosmik telah ditekankan oleh al-Qur'an, QS. al-Rum[30]:21

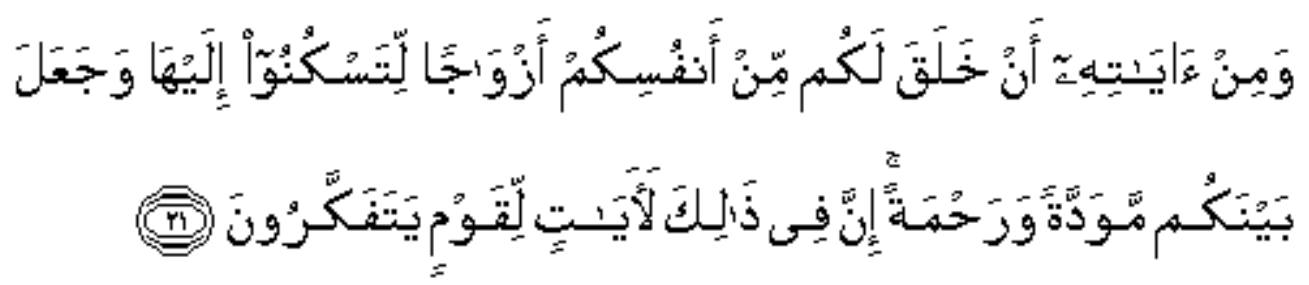

Artinya: Dan di antara tanda-tanda kekuasaan-Nya adalah diciptakan-Nya untukmu pasangan hidup dari jenismu sendiri, supaya kamu merasa condong kepadanya, dan 
dijadikan-Nya rasa cinta kasih di antara kamu. Sesungguhnya yang demikian itu, terdapat tanda-tanda kekuasaan Allah bagi orang-orang yang berpikir.

Islam tidak mengutuk seks; Islam bahkan menganggap seks itu suci, penting dan baik. Islam tidak hanya mengizinkan, bahkan menganjurkan manusia - laki-laki dan perempuan - agar memenuhi kebutuhan seksual mereka. Sebagaimana firman Allah QS. al-Baqarah [2]:223

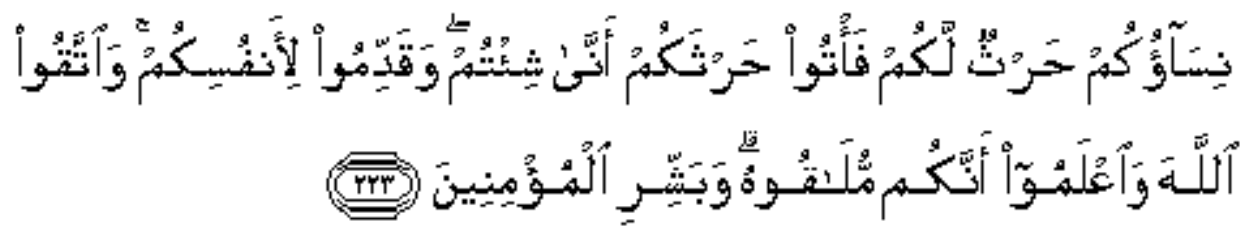

Artinya: Istri-istrimu adalah ladang bagimu. Maka datangilah mereka, kapan dan bagaimana (pun) kamu kehendaki.

Akan tetapi, Islam tidak menganggap seks sebagai satu-satunya tujuan perkawinan. Perkawinan yang hanya didasarkan pada seks semata (yaitu romantical love syndrome), adalah perkawinan yang tidak lengkap dan tidak sempurna. Perkawinan melahirkan hubungan antar manusia yang luas dan kompleks, yang merupakan materi bagi sebagian besar ketentuan moral. Di mana di dalamnya juga terdapat fungsi rekreasi, prokreasi, edukasi, afeksi, proteksi, fungsi religius dan seterusnya. Dengan demikian, dapat dikatakan di sini bahwa Islam menganggap keluarga sebagai hal yang mutlak keberadaannya, dalam rangka pemenuhan tujuan ilahi. Dan tidak akan ada Tauhid tanpa pemenuhan seperti itu. Sebab, mengakui Allah Swt. sebagai satu-satunya Tuhan, berarti mengakui bahwa kehendak dan perintah-Nya merupakan kewajiban, kebaikan dan tujuan diciptakannya manusia. Berpegang pada Tauhid berarti menghayati perintah-perintah Tuhan sebagai kewajiban, dan selanjutnya merealisasikannya dalam kehidupan nyata, yaitu mengaktualisasikan nilai-nilai yang tersirat dan yang tersurat dalam perintahperintah tersebut. Tuhan tidak hanya memerintahkan untuk mengaktualisasikan nilai-nilai tersebut, tetapi juga memberikan metode dan materi untuk melaksanakannya. Dan materinya adalah keluarga. Oleh karena itu, tidak mungkin ada Tauhid tanpa ada keluarga. $^{7}$

${ }^{7}$ Ibid, h. 138-140 
Menurut Lamya Al-Faruqi, al-Qur'an berulangkali menekankan saling ketergantungan antara laki-laki dan perempuan dalam keluarga, misalnya suami dan istri digambarkan sebagai pakaian (libas) bagi masing-masing, QS. al-Baqarah[2]:187; sebagai teman yang hidup dan tinggal bersama dalam kesentosaan, QS. al-Ahzab[33]:21 ${ }^{9}$ dan QS. al-A'raf[7]:189. ${ }^{10}$ Laki-laki dan perempuan diperintahkan untuk saling melengkapi, QS. at-Taubah[9]:71. ${ }^{11}$ Masing-masing diperintahkan untuk memenuhi tanggungjawab tertentu yang telah ditetapkan bagi kebaikan keduanya dan keluarga secara keseluruhan.

Dalam rangka menjamin sikap saling membutuhkan yang begitu penting bagi kemaslahatan fisik dan kejiwaan, baik laki-laki dan perempuan, maka Allah menetapkan di dalam al-Qur'an tugas-tugas dan kewajiban timbal balik dari berbagai angota keluarga; laki-laki dan perempuan, ayah dan ibu, anak-anak dan orang-orang yang lebih tua, serta kerabat dari semua tingkatan: QS. al-A'raf[7]:23; ${ }^{12}$ QS. an-Nisa' [4]:1 ${ }^{13}$; QS. al-Baqarah[2]:177:14 QS. al-Anfal[8]:14 ${ }^{15}$; dan QS. an-Nahl[16]:90. ${ }^{16}$

${ }^{8}$ Artinya: "Dihalalkan bagi kamu pada malam hari bulan puasa bercampur dengan istri-istrimu; mereka adalah pakaian bagimu, dam kamupun adalah pakaian bagi mereka”.

${ }^{9}$ Artinya: "Sesungguhnya telah ada pada (diri) Rasulullah Saw. suri teladan yang baik bagimu (yaitu) bagi mereka yang mengharapkan (rahmat) AllahSwt. dan (kedatangan) hari kiamat dan dia banyak menyebut Allah".

${ }^{10}$ Artinya: "Dialah Yang menciptakan kamu dari diri (jenis) yang satu dan dari padanya Dia menciptakan istrinya, agar dia merasa senang kepadanya”.

11 Artinya: "Dan orang-orang yang beriman - laki-laki dan perempuan - sebahagian mereka (adalah) menjadi penolong bagi sebahagian yang lain”.

12 Artinya: "Keduanya berkata: "Ya Tuhan kami, kami telah menganiaya diri kami sendiri, dan jika Engkau tidak mengampuni kami dan memberikan rahmat kepada kami, niscaya pastilah kami termasuk orang-orang yang merugi”.

13 Artinya: "Wahai sekalian manusia, bertakwalah kepada Tuhan-mu yang telah menciptakan kamu dari seorang diri, dan dari padanya Allah menciptakan pasangannya (istrinya); dan dari pada keduanya Allah memperkembangbiakkan laki-laki dan perempuan yang banyak. Dan bertakwalah kepada Allah yang dengan (mempergunakan) nama-Nya kamu saling meminta satu sama lain, dan (peliharalah) hubungan silaturrahim. Sesungguhnya Allah selalu menjaga dan mengawasi kamu”.

${ }^{14}$ Artinya: "Bukanlah menghadapkan wajahmu ke arah timur dan barat itu suatu kebajikan, akan tetapi sesungguhnya kebajikan itu adalah beriman kepada Allah, hari kemudian, malaikat-malaikat, kitabkitab, nabi-nabi, dan memberikan harta yang dicintainya kepada kerabatnya, anak-anak yatim, orangorang miskin, musafir (yang memerlukan pertolongan) dan orang-orang yang meminta-minta; dan (memerdekakan) hamba sahaya, mendirikan shalat, dan menunaikan zakat; dan orang-orang yang menepati janjinya apabila ia berjanji, dan orang-orang yang sabar dalam kesempitan, penderitaan dan dalam peperangan. Mereka itulah orang-orang yang benar (imannya); dan mereka itulah orang-orang yang bertakwa". 
Lebih jauh, Lamya menawarkan konsep keluarga 'Ailah sebagai keluarga Tauhid atau keluarga Qur'ani, dan itu adalah Extended Family atau keluarga besar. Di dalam keluarga besar tidak hanya ada ayah, ibu dan anak-anak, tetapi juga kakek, nenek, paman, bibi, dan kerabat lainnya. Pola kehidupan keluarga 'Ailah ini tidak hanya karena mereka tinggal bersama secara komunal, tetapi lebih pada adanya ikatan-ikatan yang kuat secara emosional, psikologis, sosial, ekonomi, dan bahkan secara politik.

Solidaritas kaluarga 'Ailah (keluarga besar) ditetapkan dan diperkuat oleh alQur'an, dimana kita menemukan rujukan yang berulang-ulang terhadap hak-hak kerabat; QS. al-Isra'[17]:23, ${ }^{17}$ perlunya memperlakukan mereka dengan baik, QS. alBaqarah[2]:83. ${ }^{18}$ Hukuman yang besar disediakan bagi mereka yang mengabaikan ketetapan-ketetapan bagi dukungan dalam keluarga, QS. an-Nisa'[4]:7. Dengan demikian keluarga besar ('Ailah) dalam Islam bukan semata-mata suatu hasil dari kondisi-kondisi sosial, tetapi merupakan suatu lembaga yang secara langsung bersandar pada ketentuan, petunjuk dan aturan-aturan Allah Swt. Faedah dari keluarga 'Ailah ini antara lain:

1. Melindungi dari sikap keakuan (selfishness) atau kegilaan salah satu pihak, karena individu tidak saja menghadapi seorang pasangan tunggal, tetapi seluruh anggota keluarga.

2. Memungkinkan terbinanya karir wanita (istri/ibu) tanpa harus mengorbankan tugas-tugas rumah tangga (domestik), karena selalu ada anggota keluarga lain

15 Artinya: "Itulah (hukum dunia yang ditimpakan atasmu), maka rasakanlah hukuman itu. Sesungguhnya bagi orang-orang yang kafir itu ada (lagi) azab neraka”.

${ }^{16}$ Artinya: "Sesungguhnya Allah menyuruh (kamu) berlaku adil dan berbuat kebajikan, memberi kepada kaum kerabat, dan Allah melarang dari perbuatan keji, kemungkaran dan permusuhan. Dia memberi pengajaran kepadamu agar kamu dapat mengambil pelajaran”.

${ }^{17}$ Artinya: "Dan Tuhanmu telah memerintahkan supaya kamu jangan menyembah selain Dia, dan hendaklah kamu berbuat baik kepada ibu bapakmu dengan sebaik-baiknya. Jika salah seorang di antara keduanya atau kedua-duanya sampai berumur lanjut dalam pemeliharaanmu, maka sekali-kali janganlah kamu mengatakan kepada keduanya perkataan "ah" dan janganlah kamu membentak mereka, dan ucapkanlah kepada mereka perkataan yang mulia”.

18 Artinya: "Dan (ingatlah), ketika Kami mengambil janji dari Bani Israil (yaitu): Janganlah kamu menyembah selain Allah, dan berbuat baiklah kepada ibu bapak, kaum kerabat, anak-anak yatim, dan orang-orang miskin, serta ucapkanlah kata-kata yang baik kepada manusia, dirikanlah shalat, dan tunaikanlah zakat. Kemudian kamu tidak memenuhi janji itu, kecuali sebahagian kecil dari pada kamu, dan kamu selalu berpaling". 
yang siap membantu atau mengambil alih tugas istri. Wanita-wanita karir dalam keluarga 'Ailah tidak akan menderita beban fisik atau emosi karena kelebihan kerja atau perasaan bersalah karena mengabaikan tanggungjawab sebagai ibu, sebagai istri maupun sebagai anggota keluarga.

Sesungguhnya lembaga keluarga 'Ailah ini adalah jalan keluar satusatunya yang dapat menjadi solusi terhadap masalah-masalah keluarga yang tengah dihadapi masyarakat Barat. Semakin banyak wanita yang bekerja di luar rumah mengakibatkan keluarga inti (nuclear family) tidak mampu lagi memenuhi kebutuhan-kebutuhan anggotanya. Permasalahan-permasalahan orang tua dalam keluarga inti sangat kompleks dan berlipat ganda. Khususnya kepada istri yang bekerja, akan berdampak buruk terhadap anak, ikatan perkawinan dan keluarga secara keseluruhan. Pemutusan hubungan keluarga dan keterpecahan psikologis dan sosial yang mengakibatkan tingkat perceraian yang begitu tinggi di Amerika dan negara-negara Barat lainnya, ${ }^{19}$ menjadi perhatian para dokter, ahli hukum, psikiater dan sosiolog, dalam hal ini berkaitan dengan mereka yang menjadi korban dalam keluarga.

3. Keluarga 'Ailah menjamin sosialisai yang memadai bagi anak-anak. Nasihat ayah atau ibu dalam sebuah keluarga inti atau keluarga orang tua tunggal (singleparent family) mungkin akan sulit dipatuhi oleh seorang anak yang "bandel” dan keras kepala, tetapi dengan adanya "tekanan" dari anggota-anggota keluarga yang lain di dalam sebuah keluarga 'Ailah, maka hal ini sangat membantu mengatasi ketidakpatuhan dan ketidakdisiplinan anak.

4. Keluarga 'Ailah memberikan keragaman psikologis dan sosial dalam kebersamaan bagi orang dewasa maupun anak-anak. Karena kurang adanya ketergantungan kepada pola hubungan tunggal, maka tidak ada tuntutan-tuntutan emosional pada masing-masing anggota keluarga. Perbedaan atau perselisihan

\footnotetext{
${ }^{19}$ Masalah-masalah impotensi yang semakin meluas pada laki-laki masa kini mungkin sebagian besar merupakan akibat kebebasan seksual yang berlebihan yang menyangkut banyak masyarakat pada abad ini, Lihat G.L. Ginsberg, “The New Impotency” dalam Archives of General Psychology 28 (1972):218
} 
antara orang-orang dewasa, anak-anak atau antara individu dari generasi yang berbeda tidak sampai berakibat merusak hubungan, sebagaimana yang terjadi dalam keluarga inti. Selalu ada anggota keluarga "alternatif" yang berperan menyelesaikan persoalan dan menjadi penengah, yang disebut juga therapeutic role atau peran terapis.

5. Keluarga 'Ailah mencegah kemungkinan terjadinya jurang pemisah antar generasi. Problem sosial ini muncul ketika masing-masing kelompok usia saling terpisah antara satu dengan yang lain, sehingga sangat sulit untuk membangun interaksi yang bermakna dengan tingkat usia yang berbeda. Dalam keluarga 'Ailah tiga generasi atau lebih hidup bersama dan secara terus-menerus saling berinteraksi. Situasi ini memberikan pelajaran yang bermanfaat dan pengalaman sosialisasi bagi anak-anak dan adanya perasaan aman terutama bagi anggota keluarga yang berusia lanjut.

6. Keluarga 'Ailah menghilangkan masalah kesepian yang menghinggapi para anggota keluarga yang (hidup) terpisah dan menyendiri di pusat-pusat kota dalam masyarakat modern. Perempuan yang belum menikah atau para janda dalam keluarga 'Ailah tidak akan mengalami masalah sebagaimana yang dialami oleh perempuan-perempuan (yang berstatus sama) dalam masyarakat Amerika sekarang ini. Dalam masyarakat Tauhid atau masyarakat Qur'ani tidak diperlukan biro jodoh, klub bujangan dan panti jompo bagi para manula (senior citizens) sebagai tempat "pembuangan" di hari tua. Kebutuhan-kebutuhan sosial dan psikologis setiap individu, baik laki-laki maupun perempuan selalu terpenuhi dalam keluarga 'Ailah.

Disaat ikatan perkawinan semakin rentan dalam masyarakat Barat, kaum perempuan cenderung menjadi korban utama dari perubahan itu. Perempuan (umumnya) kurang mampu membina dan membangun kembali ikatan perkawinan dibandingkan dengan laki-laki, dan secara psikologis mereka lebih hancur akibat runtuhnya perkawinan. 
7. Keluarga 'Ailah memberikan perawatan yang lebih masuk akal dan lebih manusiawi terhadap para manula. Dalam keluarga inti, perawatan terhadap para manula dari satu pasangan mungkin sepenuhnya dibebankan kepada satu orang, dalam hal ini adalah ibu atau istri. Dia harus memberikan perawatan fisik maupun pemenuhan emosional. Ini merupakan beban yang sangat berat bagi seorang perempuan yang mungkin memilikki beberapa orang anak serta suami yang harus dilayani kebutuhannya juga. Jika ia seorang wanita karir atau bekerja di luar rumah, maka tanggung jawabnya di rumah menjadi terabaikan, dan para manula pun akhirnya harus dititipkan di panti jompo sambil "menunggu" ajal tiba. Dengan adanya pembagian tugas dan tanggung jawab seperti dalam keluarga 'Ailah, maka beban dan permasalahan di dalam keluarga akan dapat diatasi dengan baik. ${ }^{20}$

Dalam hubungannya dengan keluarga Tauhid ini, Al-Faruqi melihat ada beberapa masalah kontemporer yang perlu mendapatkan perhatian serius, demi terciptanya keluarga yang harmonis, yang dicita-citakan, yaitu:

\section{Persamaan Derajat Antara Laki-Laki dan Perempuan}

Menurut Al-faruqi, pendapat yang mengatakan bahwa Islam membedakan kedudukan antara laki-laki dan perempuan adalah tidak benar sama sekali. Karena Allah telah menciptakan keduanya sederajat dalam hak-hak keagamaan, etika, dan sosial, serta tugas dan kewajiban mereka. Di bidang keagaman, Allah Swt. telah menetapkan kesamaan derajat antara laki-laki dan perempuan dalam QS. al-'Imran[3]:195, ${ }^{21}$

${ }^{20}$ Lamya Al-Faruqi, op. cit. h. 102-107

21 Artinya: "Maka Tuhan mereka memperkenankan permohonannya (dengan berfirman): "Sesungguhnya Aku tidak menyia-nyiakan amal orang-orang yang beramal di antara kamu, baik laki-laki atau perempuan, (karena) sebagian kamu adalah turunan dari sebagian yang lain. Maka orang-orang yang berhijrah, yang diusir dari kampong halamannya, yang disakiti pada jalan-Ku, yang berperang dan yang dibunuh, pastilah akan Ku-hapuskan kesalahan-kesalahan mereka dan pastilah Aku masukkan mereka ke dalam surga yang mengalir sungai-sungai di bawahnya, sebagai pahala di sisi Allah. Dan Allah pada sisi-Nya pahala yang baik”. 
QS. at-Taubah[9]:71-72, ${ }^{22}$ dan QS. an-Nahl[16]:97. ${ }^{23}$ Ayat-ayat ini juga menyatakan kesamaan etis mereka. Kesaman derajat dalam masyarakat dikemukakan dalam QS. al-Mumtahanah[60]:12, ${ }^{24}$ QS. al-Maidah[5]:38, ${ }^{25}$ QS. an-Nur[24]:2, ${ }^{26}$ dan QS. an-Nisa' [4]:32. ${ }^{27}$

Akan tetapi ada sedikit pengecualian, berkenaan dengan fungsi sebagai ayah dan ibu. Dalam hal ini, laki-laki menempati kedudukan lebih tinggi, sebab patrilinealisme merupakan satu-satunya bentuk kehidupan keluarga yang telah dipraktekan dan diikuti oleh manusia sejak awal mula penciptaan. Khususnya untuk bekerja di luar rumah, nampaknya laki-laki lebih memiliki kesiapan (secara fisik dan mental) dibandingkan perempuan.

\section{Pembedaan Peranan}

22 (71) Artinya: “Dan orang-orang yang beriman, laki-laki dan perempuan, sebahagian mereka (adalah) menjadi penolong bagi sebahagian yang lain. Mereka menyuruh (mengerjakan) yang ma'ruf, mencegah dari yang munkar, mendirikan shalat, menunaikan zakat, dan mereka taat pada Allah dan rasulNya. Mereka itu akan diberi rahmat oleh Allah; Sesungguhnya Allah Maha Perkasa lagi Maha Bijaksana”. (72) "Allah menjanjikan kepada orang-orang mukmin, laki-laki dan perempuan, (akan mendapat) surga yang di bawahnya mengalir sungai-sungai, mereka kekal di dalamnya, dan (mendapat) tempat-tempat yang bagus di surga 'And. Dan keridhaan Allah adalah lebih besar; itu adalah keberuntungan yang besar".

23 Artinya: "Barangsiapa yang mengerjakan amal saleh, baik laki-laki maupun perempuan dalam keadaan beriman, maka sesungguhnya akan Kami berikan kepada kehidupan yang baik dan sesungguhnya akan Kami berikan balasan kepada mereka dengan pahala yang lebih baik dari apa yang telah mereka kerjakan".

${ }^{24}$ Artinya: "Wahai Nabi, apabila datang kepadamu perempuan-perempuan yang beriman untuk mengadakan janji setia, bahwa mereka tidak akan menyekutukan Allah, tidak akan mencuri, tidak akan berzina, tidak akan membunuh anak-anaknya, tidak akan berbuat dusta yang mereka ada-adakan antara tangan dan kaki mereka dan tidak akan mendurhakaimu dalam urusan yanga baik, maka terimalah janji setia mereka dan mohonkanlah ampunan kepada Allah untuk mereka. Sesungguhnya Allah Maha Pengampun lagi Maha Penyayang”.

25 Artinya: "Laki-laki yang mencuri dan perempuan yang mencuri, potonglah tangan keduanya (sebagai) pembalasan bagi apa yang mereka kerjakan dan sebagai siksaan dari Allah. Dan allah Maha Perkasa lagi Maha Bijaksana”.

${ }^{26}$ Artinya: "Perempuan yang berzina dan laki-laki yang berzina, maka deralah tiap-tiap seorang dari keduanya seratus kali dera, dan janganlah belas kasihan kepada keduanya mencegah kamu untuk (menjalankan) agama Allah, jika kamu beriman kepada Allah, dan hari akhirat, dan hendaklah (pelaksanaan) hukuman mereka disaksikan oleh sekumpulan orang-orang yang beriman”.

27 Artinya: "Dan janganlah kamu iri hati terhadap apa yang dikaruniakan Allah kepada sebahagian kamu lebih banyak dari sebahagian yang lain. (Karena) bagi laki-laki ada bahagian dari apa yang mereka usahakan, dan bagi perempuan (pun) ada bahagian dari apa yang mereka usahakan, dan mohonlah kepada Allah sebagian dari karunia-Nya. Sesungguhnya Allah Maha Mengetahui segala sesuatu”. 
Menurut Al-Faruqi, Islam menganggap laki-laki dan perempuan diciptakan untuk fungsi-fungsi yang berbeda tetapi saling melengkapi. Peran sebagai ibu; pengatur rumah tangga dan pengasuh anak, dan peran sebagai ayah; pelindung, pencari nafkah dan pemikul seluruh tanggungjawab rumah tangga. Semuanya itu menuntut syarat-syarat fisik, psikis dan emosional yang berlainan antara laki-laki dan perempuan. Islam menganggap pembedaan (distinction) ini perlu, demi pemenuhan diri antara laki-laki dan perempuan. Perbedaan peranan sama sekali bukan diskriminasi (discrimination) dan segregasi (segregation). Kedua peran ini sama-sama tunduk di bawah norma-norma agama dan etika; dan keduanya membutuhkan kecerdasan, bakat, energi dan usaha yang sungguh-sungguh dari kedua belah pihak, laki-laki dan perempuan.

\section{Kesimpualan}

Pada dasarnya ada tiga elemen penting yang membentuk sebuah masyarakat; yaitu manusia sebagai individu, keluarga dan ummat. Ketiga elemen ini diibaratkan oleh Al-Faruqi sebagai the three sides of one coin, yang tidak bisa dipisahkan satu sama lain, tetapi saling melengkapi. Namun, elemen yang paling utama adalah keluarga, karena secara prinsip, keluargalah yang paling berperan membentuk sumber daya manusia seorang individu dan masyarakat. Keluarga adalah tempat menanamkan nilai-nilai Tauhid dan moral keagamaan. Karenanya tanpa keluarga, maka tidak mungkin nilai-nilai Tauhid dapat disosialisasikan. Dan berdasarkan keterangan-keterangan dari al-Qur'an bahwa keluarga 'Ailah (dalam istilah Lamya Al-Faruqi) atau dalam sosiologi disebut sebagai extended family adalah "model" keluarga Qur'ani yang akan dapat menyelesaikan persoalan-persoalan keluarga yang sedang dihadapi masyarakat kontemporer, khususnya di Barat (Amerika). 


\section{DAFTAR PUSTAKA}

Al-Faruqi, Ismail Raji, T a u hi d, pent. Rahmani Astuti, (Bandung: Pustaka, 1988)

Trialogue of the Abrahamic Faith, (Maryland: Amana Publication, 1982)

Al-Faruqi, Lamya, 'Ailah; Masa Depan Kaum Wanita, pent. Masyhur Abadi, (Surabaya: Pustaka, 1997)

Hornby, AS., Oxfor Advanced Learner's Dictionary of Current English, (England: Oxford University Press, 1974)

Nye, F. Ivan, et.al., Role Structure and Analysis of the Family, (London-Beverly Hills: SAGE Publications, 1976)

Rahman, Fazlur, I s l a m, pent. Ahsin Mohammad, (Bandung: Pustaka, 2003). 